\title{
PERBEDAAN EFEKTIVITAS TERAPI MUSIK KLASIK DENGAN TERAPI MURATAL TERHADAP GEJALA KECEMASAN; FASE 2 PADA LANSIA DI PANTI WERDHA BINJAI
}

\author{
Juliandi \\ Jurusan Keperawatan Poltekkes Kemenkes Medan
}

\begin{abstract}
Abstrak
Terapi musik diketahui bahwa rangsangan music ternyata mampu mengaktivasi system Limbik yang berhubungan emosi. Saat system Limbik teraktivasi otak menjadi rileks. Terapi dengan mendengarkan lantunan muratal AlQur'an ternyata sudah memasyarakat di kalangan tertentu pemeluk agama Islam. Tujuan mereka bukan sebagai terapi suara, tetapi untuk mendekatkan diri kepada Tuhan (Allah SWT). Hasil prediksi menunjukkan bahwa persentase penduduk lanjut usia akan mencapai 9,77 \% dari total penduduk pada tahun 2010 dan menjadi $11,34 \%$ pada tahun 2020.

Tujuan penelitian adalah untuk mengetahui apakah ada perbedaan tingkat efektivitas pada terapi musik klasik dan terapi murotal dalam menurunkan kecemasan fase 2.

Hasil penelitian menunjukkan bahwa perbedaan gejala kecemasan fase 2 pada lansia sesudah terapi musik klasik dengan terapi muratal adalah rata-rata sebesar 1,38235 dengan standar deviasi sebesar 0,60376. Terapi muratal lebih efektif 1,59 kali dibandingkan terapi musik klasik yaitu sebesar 1,17169 kali terhadap gejala kecemasan fase 2 pada lansia. Hasil analisis statistik dengan menggunakan uji paired $t$-test menunjukkan bahwa p-value sebesar 0,000 , artinya ada perbedaan yang sangat signifikan antara efektivitas terapi musik klasik dengan terapi muratal sesudah perlakuan terhadap gejala kecemasan fase 2 pada lansia.

Diharapkan dari hasil penelitian ini dapat digunakan sebagai bahan masukan dalam upaya peningkatan mutu pelayanan kesehatan dibidang keperawatan, khususnya keperawatan geriatrik guna menurunkan gejala kecemasan; fase 2 .
\end{abstract}

Kata Kunci : Terapi musik klasik, terapi murotal, kecemasan fase 2

\section{PENDAHULUAN}

Proses menua merupakan proses sepanjang hidup, yang ditandai dengan kegagalan tubuh dalam mempertahankan homeostasis tubuh terhadap tekanan fisiologis yang menyebabkan terjadinya perubahan struktur tubuh dan perubahan fungsional sehingga menyebabkan adanya gangguan, ketidak mampuan dan sering terjadi penyakit (Rochman \& Aswin, 2001).

Kini telah banyak dikembangkan terapi-terapi keperawatan untuk menangani kecemasan, diantaranya adalah terapi musik dan terapi murotal yang dapat mengurangi tingkat kecemasan pada pasien.Terapi murotal dan terapi musik dapat menurunkan kecemasan, tetapi apakah terapi murotal itu lebih cepat menurunkan kecemasan dibandingkan terapi musik belum diketahui, sehingga diperlukan penelitian tentang keefektivan antara pemberian terapi pembacaan Al-Qur'an dengan terapi musik terhadap penurunan kecemasan pada pasien preoperasi. Tujuan - Tujuan penelitian adalah untuk mengetahui apakah ada perbedaan tingkat efektivitas pada kedua terapi dalam menurunkan kecemasan

Terapi musik diketahui bahwa rangsangan musik ternyata mampu mengaktivasi sistem Limbik yang berhubungan emosi. Saat sistem Limbik teraktivasi otak menjadi rileks. Kondisi inilah yang memicu tekanan darah menurun. Dalam Terapi musik, Alunan musik juga dapat menstimulasi tubuh untuk memproduksi molekul nitric oxide (NO). Molekul ini bekerja pada tonus pembuluh darah yang dapat mengurangi tekanan darah.Cara Menjalini

Musik memiliki fungsi untuk meningkatkan, mengubah emosi dan aspek spiritual (Sloboda, 1999 cit. Djohan, 2008). Musik merupakan sarana untuk menata dan meningkatkan kualitas diri baik pada aspek kognitif, emosi maupun fisik (Denora 1997 cit. Djohan, 2008). Peningkatan kompleksitas kehidupan dan tekanan dalam pekerjaan dapat berakibat negatif pada manusia. Saat ini telah ada banyak pilihan cara yang dapat dilakukan agar selalu berada tegar dalam menghadapi gangguan (tekanan/stress).

Muratal Al-Qur'an sudah menjadi musik tersendiri bagi umat muslim. Terapi dengan mendengarkan lantunan muratal Al-Qur'an ternyata sudah memasyarakat di kalangan tertentu pemeluk agama Islam. Tujuan mereka bukan sebagai terapi suara, tetapi untuk mendekatkan diri kepada Tuhan (Allah SWT). Praktik ini tidak saja dilakukan terhadap orang dewasa tetapi juga anak-anak (Abdurrochman, et al., 2007). Penjelasan sebelumnya mengunggapkan bahwa lansia beresiko mengalami gangguan tidur. Gangguan tidur tersebut dapat direduksi dengan mendengarkan musik atau suara yang bertempo rendah. Muratal Al-Qur'an sendiri, merupakan bagian dari musik tersebut.

Penelitian yang dilakukan oleh Abdurrahman dkk di RS Moewardi Surakarta tentang pemberian terapi 
musik klasik dengan muratal adalah sebagai berikut sebelum diberikan terapi sebagian besar pasien mengalami cemas sedang. Uji beda tingkat kecemasan dengan terapi musik diperoleh nilai thitung, sebesar 8,887 $(\mathrm{p}=0,000<0,05)$ sehingga Ho ditolak. Artinya pemberian terapi musik efektif menurunkan tingkat kecemasan pasien.

Uji beda tingkat kecemasan dengan terapi murotal diperoleh nilai thitung, sebesar 10,920 (p : 0,000 $<0,05)$ sehingga Ho ditolak artinya pemberian terapi murotal efektif menurunkan kecemasan pasien. Uji beda tingkat kecemasan dengan terapi musik dan murotal diperoleh nilai t66n, sebesar 2,946 ( $\mathrm{p}=0,000<0,05)$ sehingga Ho ditolak artinya pemberian terapi murotal lebih efektif menurunkan tingkat kecemasan pasien dibandingkan dengan terapi musik.

Survei awal ke Panti Werdha Binjai pada bulan Januari 2017 didapati data jumlah Lansia pada Panti Werdha Binjai pada tahun 2016 sebanyak 160 orang yang terdiri dari 74 laki-laki dan 86 perempuan. Awal mula peneliti datang ke Panti Werdha Binjai, peneliti yang didampingi oleh perawat yang bertugas disana, peneliti mendapati ada 15 lansia mengalami kecemasan fase 2 seperti gelisah, ketegangan otot, gangguan tidur dan keluhan perut, penderita juga mulai tidak bisa mengontrol emosinya dan tidak ada motivasi diri. Perawat mengatakan penyebab terjadinya gejala tersebut dikarenakan kebosanan yang berlebihan, merasa diasingkan oleh keluarganya, kurang bersosialisasi dengan sesama lansia atau juga penyesuaian diri yang buruk dilingkungan tersebut.

Maka dengan dasar inilah peneliti ingin melakukan penelitian mengenai terapi musik klasik dan terapi muratal Al-Qur'an untuk mengurangi gejala kecemasan; fase 2. Diharapkan dari hasil penelitian ini dapat digunakan sebagai bahan masukan dalam upaya peningkatan mutu pelayanan kesehatan dibidang keperawatan, khususnya keperawatan geriatrik guna menurunkan gejala kecemasan; fae 2 .

Kerangka Konsep Penelitian

Adapun kerangka konsep penelitian adalah sebagai berikut:

Variabel Independent Variabel Dependent

\begin{tabular}{|l|l|}
$\begin{array}{l}\text { Terapi musik } \\
\text { klasik dan } \\
\text { muratal }\end{array}$ & Kecemasan \\
; fase 2
\end{tabular}

\section{METODE}

Jenis penelitian ini adalah quasi eksperimen tipe Pretest posttest two group design dengan dua macam perlakuan. Rancangan ini sangat baik digunakan untuk evaluasi program pendidikan kesehatan atau pelatihanpelatihan lainnya, dimana hasil perlakuan dapat diketahui lebih efektif mana yang lebih baik untuk mengurangi gejala kecemasan; fase 2 pada lansia. Penelitian ini direncanakan di Panti Werdha Binjai, di mulai bulan Januari sampai dengan Desember 2017.

Populasi dalam penelitian ini adalah seluruh pasien di Panti Werdha Binjai. Besar sebanyak 34 orang. Terapi Musik Klasik danTerapi Al-Qur'an.

Terapi musik klasik Bethoven dengan judul "Song of Joy" dan terapi muratal dengan alunan Juz Amma oleh Thaha Muhammad. Alat yang digunakan dalam penelitian ini berupa MP3 player yang dibantu dengan headset.

Lembaran Kuesioner keefektifan post test terapi musik klasik dan terapi muratal pada lansia Data yang telah terkumpul kemudian diolah dengan langkah-langkah sebagai berikut:

a. Editing, untuk memastikan bahwa kuesioner telah disisi dangan lengkap oleh responden

b. Coding, yaitu memberikan kode pada instrumen penelitian untuk mempermudah tahap berikutnya

c. Tabulating, yaitu penyajian data dalam bentuk table agar dapatdiketahui gambaran data secara umum

\section{HASIL}

Berdasarkan hasil penelitian terhadap 34 responden lanjut usia yang tinggal di Panti Werdha Binjai mengenai perbedaan keefektifan terapi musik klasik dengan terapi muratal terhadap gejala kecemaan fase 2 maka didapatkan hasil penelitian berdasarkan karakteristik responden sebagai berikut:

Karakteristik Responden berdasarkan Jenis Kelamin Karakteristik responden berdasarkan jenis kelamin dapat dilihat pada tabel dibawah ini :

\section{Karakteristik Responden berdasarkan Jenis Kelamin}

\begin{tabular}{clcc}
\hline No & JenisKelamin & f & \% \\
\hline 1 & Laki-laki & 16 & 47.1 \\
2 & Perempuan & 18 & 52.9 \\
\hline & Total & 34 & 100.0 \\
\hline
\end{tabular}

Sumber : Hasil penelitian 2017

Berdasarkan tabel 5.1 diketahui bahwa jumlah responden laki-laki lebih sedikit dibandingkan dengan jumlah subjek perempuan. Responden laki-laki sebanyak 16 orang $(47,1 \%)$ dan responden perempuan sebanyak 18 orang $(52,9 \%)$ dengan penyebarannya dapat dilihat pada gambar 5.1 berikut ini:

\section{Karakteristik Responden berdasarkan Umur}

Karakteristik responden berdasarkan umur dapat dilihat pada tabel dibawah ini:

Karakteristik Responden berdasarkan Umur

\begin{tabular}{cccc}
\hline No & Umur & f & \% \\
\hline 1 & $50-60$ tahun & 5 & 14.7 \\
2 & $61-70$ tahun & 16 & 47.1 \\
3 & $71-80$ tahun & 11 & 32.4
\end{tabular}




\begin{tabular}{rccc}
4 & $>80$ tahun & 2 & 5.9 \\
\hline Total & $\mathbf{3 4}$ & $\mathbf{1 0 0 . 0}$ \\
\hline
\end{tabular}

Sumber : Hasil penelitian 2017

Berdasarkan tabel 5.2 diketahui bahwa dari 34 responden, paling banyak responden berada pada usia antara 61-70 tahun yaitu sebanyak 16 orang (47,1\%), diikuti responden usia antara 71-80 tahun sebanyak 11 orang $(32,4 \%)$, selanjutnya responden usia antara 50-60 tahun sebanyak 5 orang $(14,7 \%)$ dan paling sedikit responden usia lebih dari 80 tahun yaitu ada 2 orang $(5,9 \%)$. Penyebaran responden berdasarkan usia ini dapat dilihat pada gambar 5.2 berikut ini:

\section{Karakteristik Responden berdasarkan Suku}

Karakteristik responden berdasarkan umur dapat dilihat pada tabel dibawah ini:

Tabel Karakteristik Responden berdasarkan Suku

\begin{tabular}{clcc}
\hline No & Suku & f & \% \\
\hline 1 & Jawa & 11 & 32.4 \\
2 & Batak & 13 & 38.2 \\
3 & Banjar & 2 & 5.9 \\
4 & Banten & 1 & 2.9 \\
5 & Betawi & 1 & 2.9 \\
6 & Melayu & 2 & 5.9 \\
7 & NTT & 1 & 2.9 \\
8 & Aceh & 1 & 2.9 \\
9 & Kalimantan & 1 & 2.9 \\
10 & Minang & 1 & 2.9 \\
\hline \multicolumn{2}{c}{ Total } & $\mathbf{3 4}$ & $\mathbf{1 0 0 . 0}$ \\
\hline
\end{tabular}

Sumber : Hasil penelitian 2017

Berdasarkan tabel 5.3 diketahui bahwa dari 34 responden, paling banyak responden suku Batak yaitu sebanyak 13 orang $(38,2 \%)$, diikuti responden suku Jawa sebanyak 11 orang $(32,4 \%)$, selanjutnya responden suku Banjar dan suku Melayu masing-masing sebanyak 2 orang $(5,9 \%)$ dan paling sedikit responden suku Banten, Betawi, NTT, Aceh, Kaimantan dan Minang yaitu masing-masing ada 1 orang (2,9\%). Penyebaran responden berdasarkan suku ini dapat dilihat pada gambar 5.3 berikut ini:

\section{Karakteristik Responden berdasarkan Pendidikan Terakhir}

Karakteristik responden berdasarkan umur dapat dilihat pada tabel dibawah ini:

Tabel Karakteristik Responden berdasarkan PendidikanTerakhir

\begin{tabular}{clcc}
\hline No & $\begin{array}{l}\text { Pendidikan } \\
\text { Tingkat }\end{array}$ & f & \% \\
\hline 1 & SD/SR & 18 & 52.9 \\
2 & SMP & 11 & 32.4 \\
3 & SMA/Sederaj & 5 & 14.7 \\
& at & & \\
4 & Total & 34 & 100.0 \\
\hline & $\quad$ Total & $\mathbf{3 4}$ & $\mathbf{1 0 0 . 0}$ \\
\hline
\end{tabular}

Sumber : Hasil penelitian 2017
Berdasarkan tabel 5.4 diketahui bahwa dari 34 responden, paling banyak responden dengan tingkat pendidikan terakhir SD/SR yaitu sebanyak 18 orang (52,9\%), diikuti responden dengan tingkat pendidikan terakhir SMP yaitu sebanyak 11 orang $(32,4 \%)$ dan paling sedikit responden dengan tingkat pendidikan terakhir SMA/sederajat sebanyak 5 orang ( Penyebaran responden berdasarkan pendidikan ini dapat dilihat pada gambar 5.2 berikut ini:

\section{Penyebaran Responden berdasarkan Tingkat Pendidikan}

Analisis Univariat

Distribusi Frekuensi Responden Sebelum dan Sesudah Terapi Musik Klasik terhadap Gejala Kecemasan Fase 2 pada Lansia di Panti Werdha Binjai

Dari hasil penelitian menunjukkan distribusi frekuensi responden sebelum dan sesudah terapi musik klasik terhadap gejala kecemasan fase 2 pada lansia di Panti Werdha Binjai adalah sebagai berikut:

Distribusi Frekuensi Responden Sebelum dan Sesudah Terapi Musik Klasik terhadap Gejala Kecemasan Fase 2 pada Lansia di Panti Werdha Binjai

\begin{tabular}{cccccc}
\hline & Gejala & \multicolumn{2}{c}{ Sebelum } & \multicolumn{2}{c}{ Sesudah } \\
o & Kecemas & F & \% & F & \% \\
& an & & & & \\
1 & Baik & - & - & - & - \\
2 & Cukup & 9 & 26.5 & 14 & 41.2 \\
3 & Kurang & 25 & 73.5 & 20 & 58.8 \\
\hline & Jumlah & 34 & 100. & 34 & 100. \\
& & & 0 & & 0 \\
\hline
\end{tabular}

Sumber : Hasil penelitian 2017

Berdasarkan Tabel 5.5 diatas dapat diketahui bahwa responden dengan gejala kecemasan fase 2 sebelum terapi musik klasik cukup baik ada 9 orang (26,5\%), kurang baik sebanyak 25 orang $(73,5 \%)$ dan tidak ada lansia yang memiliki gejala kecemasan baik. Setelah responden melakukan terapi musik klasik ada peningkatan sedikit yaitu responden dengan gejala kecemasan fase 2 cukup baik bertambah 5 orang menjadi 14 orang $(41,2 \%)$, kurang baik berkurang 5 orang menjadi 20 orang $(58,8 \%)$ dan tidak ada responden dengan gejala kecemasan baik.

Distribusi Frekuensi Responden Sebelum dan Sesudah Terapi Muratal terhadap Gejala Kecemasan Fase 2 pada Lansia di Panti Werdha Binjai

Darihasil penelitian menunjukkan distribusi frekuensi responden sebelum dan sesudah terapi muratal terhadap gejala kecemasan fase 2 pada lansia di Panti Werdha Binjai adalah sebagai berikut:

Distribusi Frekuensi Responden Sebelum dan Sesudah Terapi Muratal terhadap Gejala Kecemasan Fase 2 pada Lansia di Panti Werdha Binjai 


\begin{tabular}{clcccc}
\hline \multirow{2}{*}{ No } & Gejala & \multicolumn{2}{c}{ Sebelum } & \multicolumn{2}{c}{ Sesudah } \\
& Kecemasan & F & \% & F & \% \\
\hline 1 & Baik & - & - & 27 & 79.4 \\
2 & Cukup & 10 & 29.4 & 7 & 20.6 \\
3 & Kurang & 24 & 70.6 & - & - \\
\hline & Jumlah & 34 & 100.0 & 34 & 100.0 \\
\hline
\end{tabular}

Sumber : Hasil penelitian 2017

Berdasarkan Tabel 5.6 diatas dapat diketahui bahwa responden dengan gejala kecemasan fase 2 sebelum diberikan terapi muratal cukup baik ada 10 orang $(29,4 \%)$, kurang baik sebanyak 24 orang $(70,6 \%)$ dan tidak ada responden yang memiliki gejala kecemasan baik. Sesudah diberikan terapi muratal responden dengan gejala kecemasan fase 2 baik menjadi sebanyak 27 orang $(79,4 \%)$, cukup baik ada 7 orang $(20,5 \%)$ dan tidak ada responden yang memiliki gejala kecemasan kurang baik.

\section{Analisis Bivariat}

Perbedaan Gejala Kecemasan Fase 2 pada Lansia Sebelum Terapi Musik Klasik dan Terapi Muratal di Panti Werdha Binjai

Perbedaan gejala kecemasan fase 2 pada lansia sebelum terapi musik klasik dan Terapi Muratal di Panti Werdha Binjai adalah sebagai berikut :

Perbedaan Gejala Kecemasan Fase 2 pada Lansia Sebelum Terapi Musik Klasik dan Terapi Muratal di Panti Werdha Binjai

\begin{tabular}{lllllll}
\hline \multirow{2}{*}{ Variabel } & \multirow{2}{*}{ Mean- } & \multirow{2}{*}{ SD } & \multicolumn{2}{c}{$95 \%$ CI } & \multirow{2}{*}{-Value } & \multirow{2}{*}{$\boldsymbol{n}$} \\
\cline { 4 - 5 } $\begin{array}{l}\text { Sebelum } \\
\text { Terapi Musik }\end{array}$ & \multirow{2}{*}{02941} & .17150 & 0.8925 & 03043 & 0,325 & 34 \\
$\begin{array}{l}\text { Klasik dan } \\
\text { Terapi Muratal }\end{array}$ & & & & & & \\
\hline
\end{tabular}

Pada tabel 5.7 di atas menunjukkan bahwa perbedaan gejala kecemasan fase 2 pada lansia sebelum terapi musik klasik dan terapi muratal adalah rata-rata sebesar 0,02941 dengan standar deviasi sebesar 0,17150. Hal ini menunjukkan bahwa terapi musik klasik lebih efektif kurang dari 0,03 kali dibandingkan terapi muratal yaitu lebih efektif sebesar 0,089 kali terhadap gejala kecemasan fase 2 pada lansia.

Hasil analisis statistik dengan menggunakan $u j i$ paired t-test menunjukkan p-value sebesar 0,325, artinya tidak ada perbedaan efektivitas terapi musik klasik dengan terapi muratal sebelum perlakuan terhadap gejala kecemasan fase 2 pada lansia di Panti Werdha Binjai.

Perbedaan Gejala Kecemasan Fase 2 pada Lansia Sesudah Terapi Musik Klasik dan Terapi Muratal di Panti Werdha Binjai

Perbedaan gejala kecemasan fase 2 pada lansia sesudah terapi musik klasik dan Terapi Muratal di Panti Werdha Binjai adalah sebagai berikut :

Perbedaan Gejala Kecemasan Fase 2 pada Lansia Sesudah Terapi Musik Klasik dan Terapi Muratal di Panti Werdha Binjai

\begin{tabular}{|c|c|c|c|c|c|c|}
\hline \multirow{2}{*}{ Variabel } & \multirow{2}{*}{ Mean- } & \multirow{2}{*}{ SD } & \multicolumn{2}{|c|}{$95 \%$ CI } & \multirow{2}{*}{-p-Value } & \multirow{2}{*}{$n$} \\
\hline & & & Lower & Upper & & \\
\hline $\begin{array}{l}\text { Sesudah } \\
\text { Terapi } \\
\text { Musik } \\
\text { Klasik dan } \\
\text { Terapi } \\
\text { Muratal }\end{array}$ & 1.38235 & .60376 & 1.59302. & 1.17169 & 0,00 & 34 \\
\hline
\end{tabular}

Pada tabel 5.8 di atas menunjukkan bahwa perbedaan gejala kecemasan fase 2 pada lansia sesudah terapi musik klasik dengan terapi muratal adalah rata-rata sebesar 1,38235 dengan standar deviasi sebesar 0,60376. Terapi muratal lebih efektif 1,59 kali dibandingkan terapi musik klasik yaitu sebesar 1,17169 kali terhadap gejala kecemasan fase 2 pada lansia.

Hasil analisis statistik dengan menggunakan uji paired t-test menunjukkan bahwa p-value sebesar 0,000 , artinya ada perbedaan yang sangat signifikan antara efektivitas terapi musik klasik dengan terapi muratal sesudah perlakuan terhadap gejala kecemasan fase 2 pada lansia di Panti Werdha Binjai.

\section{PEMBAHASAN}

\section{Karakteristik Responden}

Berdasarkan hasil penelitian yang dilakukan terhadap 34 responden lanjut usia yang tinggal di Panti Werdha Binjai mengenai perbedaan keefektifan terapi musik klasik dengan terapi muratal terhadap gejala kecemaan fase 2, berdasarkan karakteristik diketahui bahwa responden di Panti Werdha Binjai lebih banyak lansia perempuan yaitu sebanyak 18 orang $(52,9 \%)$ dibandingkan laki-laki yaitu sebanyak 16 orang $(47,1 \%)$. Lansia di Panti Werdha Binjai sebagian besar berusia antara 61-70 tahun yaitu sebanyak 16 orang $(47,1 \%)$ diikuti lansia dengan usia 71-80 tahun sebanyak 11 orang $(32,4 \%)$, selanjutnya responden usia $50-60$ ada 5 orang $(14,7 \%)$, dan paling sedikit responden dengan usia lebih dari 80 tahun yaitu ada 2 orang $(5,9 \%)$. Adapun lansia di Panti Werdha Binjai sebagian besar didominasi suku Batak yaitu sebanyak 13 orang $(38,2 \%)$, diikuti lansia dengan suku Jawa sebanyak 11 orang (32,4\%), selanjutnya responden suku Banjar dan suku Melayu masing-masing sebanyak 2 orang $(5,9 \%)$ dan paling sedikit responden suku Banten, Betawi, NTT, Aceh, Kalimantan dan Minang masing-masing ada 1 orang (2,9\%). Tingkat pendidikan terakhir lansia paling banyak adalah pendidikan SD/SR yaitu sebanyak 18 orang (52,9\%), diikuti lansia dengan tingkat pendidikan terakhir SMP yaitu sebanyak 11 orang $(32,4 \%)$ dan paling sedikit responden dengan tingkat pendidikan terakhir SMA/sederajat yaitu ada 5 orang $(14,7 \%)$.

Efektivitas Terapi Musik Klasik Sebelum dan Sesudah Perlakuan terhadap Gejala Kecemasan Fase 2 pada Lansia di Panti Werdha Binjai

Dari hasil penelitian pada Tabel 5.5 distribusi frekuensi responden sebelum dan sesudah terapi musik klasik terhadap gejala kecemasan fase 2 pada lansia di Panti Werdha Binjai menunjukkan bahwa responden 
dengan gejala kecemasan fase 2 sebelum terapi musik klasik cukup baik ada 9 orang $(26,5 \%)$, kurang baik sebanyak 25 orang $(73,5 \%)$ dan tidak ada lansia yang memiliki gejala kecemasan baik. Setelah responden melakukan terapi musik klasik ada peningkatan sedikit yaitu responden dengan gejala kecemasan fase 2 cukup baik bertambah 5 orang menjadi 14 orang $(41,2 \%)$, kurang baik berkurang 5 orang menjadi 20 orang $(58,8 \%)$ dan tidak ada responden dengan gejala kecemasan baik.

Musik klasik menurut definisi Djohan (2006) adalah suatu profesi dibidang kesehatan yang menggunakan musik dan aktifitas musik untuk mengatasi berbagai masalah dalam aspek fisik, psikologis, kognitif, dan kebutuhan sosial individu yang mengalami cacat fisik.

Ketika diperdengarkan musik klasik, maka harmonisasi dalam musik klasik yang indah akan masuk telinga dalam bentuk suara (audio), menggetarkan genderang telinga, mengguncangkan cairan diteling dalam serta mengg etarkan sel-sel rambut di dalam koklea untuk selanjutnya melalui saraf koklearis menuju otak dan menciptakan imajinasi keindahan di otak kanan dan otak kiri. Yang akan memberikan dampak berupa kenyamanan dan perubahan perasaan. Perubahan perasaan ini diakibatkan karena musik klasik dapat menjangkau wilayah kiri kortek cerebri (Mindlin, 2009 dalam Garry, 2014). Dari korteks limbik, jaras pendengaran dilanjutkan ke hipokampus, dan meneruskan sinyal musik ke Amigdala yang merupakan area perilaku kesadaran yang bekerja pada tingkat bawah sadar, sinyal kemudian diteruskan ke hipotalamus.

Hipotalamus merupakan area pengaturan sebagian fungsi vegetative dan fungsi endokrin tubuh seperti halnya banyak aspek perilaku emosional, jaras pendengaran diteruskan ke formatio retikularis sebagai penyalur impuls menuju serat otonom. Serat saraf tersebut mempunyai dua sistem saraf, yaitu saraf simpatis dan para simpatis. Kedua saraf ini dapat mempengaruhi kontraksi dan relaksasi organorgan. Relaksasi dapat merangsang pusat rasa ganjaran sehingga timbul ketenangan (Ganong, 2005 dalam Garry, 2014).

\section{Efektivitas Terapi Muratal Sebelum dan Sesudah Perlakuan terhadap Gejala Kecemasan Fase 2 pada Lansia di Panti Werdha Binjai}

Dari hasil penelitian pada Tabel 5.6 distribusi frekuensi responden sebelum dan sesudah terapi muratal terhadap gejala kecemasan fase 2 pada lansia di Panti Werdha Binjai menunjukkan bahwa responden dengan gejala kecemasan fase 2 sebelum diberikan terapi muratal cukup baik ada 10 orang $(29,4 \%)$, kurang baik sebanyak 24 orang $(70,6 \%)$ dan tidak ada responden yang memiliki gejala kecemasan baik, tetapi sesudah diberikan terapi muratal responden dengan gejala kecemasan fase 2 baik menjadi sebanyak 27 orang $(79,4 \%)$, cukup baik ada 7 orang $(20,5 \%)$ dan tidak ada responden yang memiliki gejala kecemasan kurang baik.

Demikian pula dengan terapi murotal yang bisa dijadikan referensi dalam hal penurunan tingkat depresi dan gangguan kecemasan. Dalam Konferensi Tahunan ke XVII Ikatan Dokter Amerika, wilayah Missuori, Ahmad Al-Kahdi melakukan presentasi tentang hasil penelitiannya dengan tema pengaruh Al-Qur'an pada manusia dalam perspektif fisiologis dan psikologis. Hasil penelitian tersebut menunjukkan hasil positif bahwa mendengarkan ayat suci Al-Qur'an memiliki pengaruh yang signifikan dalam menurunkan ketegangan urat saraf reflektif dan hasil ini tercatat dan terukur secara kuantitatif dan kualitatif oleh sebuah alat berbasis komputer (Remolda, 2009).

Lebih lanjut menurut Abdurrochman, et.al. (2007) muratal Al-Qur'an sudah menjadi musik tersendiri bagi umat muslim. Terapi dengan mendengarkan lantunan muratal Al-Qur'an ternyata sudah memasyarakat di kalangan tertentu pemeluk agama Islam. Tujuan mereka bukan sebagai terapi suara, tetapi untuk mendekatkan diri kepada Tuhan (Allah SWT). Praktik ini tidak saja dilakukan terhadap orang dewasa tetapi juga anak-anak.

Menurut peneliti dengan tempo yang lambat serta harmonisasi Al-Qur'an, dapat menurunkan hormonhormon stres, meningkatkan perasaan rileks, dan mengalihkan perhatian dari rasa takut, cemas dan tegang, memperbaiki sistem kimia tubuh sehingga menurunkan tekanan darah serta memperlambat pernafasan, detak jantung, dan aktivitas gelombang otak.

Hasil penelitian ini didukung oleh penelitian yang dilakukan dengan pendapat Ika (2015) yang menyatakan berdasarkan uji statistik dengan menggunakan wilcoxon test didapat hasil ada pengaruh terapi musik klasik dan murottal terhadap penurunan tingkat depresi pada lansia dengan nilai $p=0,042(<0,05)$. Sedangkan untuk uji beda pengaruh didapatkan nilai $\mathrm{p}=$ $0,035(<0,05)$.

\section{Perbedaan antara Terapi Musik Klasik dengan Terapi Muratal terhadap Gejala Kecemasan Fase 2 pada Lansia di Panti Werdha Binjai}

Dari hasil penelitian pada tabel 5.7 perbedaan gejala kecemasan fase 2 pada lansia sebelum terapi musik klasik dan Terapi Muratal di Panti Werdha Binjai diketahui bahwa gejala kecemasan fase 2 pada lansia sebelum terapi musik klasik dan terapi muratal adalah rata-rata sebesar 0,02941 dengan standar deviasi sebesar 0,17150 . Hal ini menunjukkan bahwa terapi musik klasik lebih efektif kurang dari 0,03 kali dibandingkan terapi muratal yaitu lebih efektif sebesar 0,089 kali terhadap gejala kecemasan fase 2 pada lansia. Hasil analisis statistic menunjukkan p-value sebesar 0,325, artinya tidak ada perbedaan efektivitas terapi musik klasik dengan terapi muratal sebelum perlakuan terhadap gejala kecemasan fase 2 pada lansia di Panti Werdha Binjai. Sedangkan hasil penelitian pada tabel 5.8 gejala kecemasan fase 2 pada lansia sesudah terapi musik klasik dan terapi Muratal di Panti Werdha Binjai diketahui bahwa gejala kecemasan fase 2 pada lansia sesudah terapi musik klasik dengan terapi muratal adalah rata-rata sebesar 1,38235 dengan standar deviasi sebesar 0,60376. Terapi muratal lebih efektif 1,59 kali dibandingkan terapi musik klasik yaitu sebesar 1,17169 kali terhadap gejala kecemasan fase 2 pada lansia. Hasil analisis statistic menunjukkan p-value sebesar 0,000, artinya ada perbedaan yang sangat signifikan antara efektivitas terapi musik klasik dengan terapi muratal sesudah perlakuan 
terhadap gejala kecemasan fase 2 pada lansia di Panti Werdha Binjai.

Namun dari data yang didapat ternyata lebih efektif menggunakan murotal dibandingkan terapi musik klasik. Menurut peneliti hal ini karena terapi murotal memiliki aspek yang sangat diperlukan dalam mengatasi depresi, yakni kemampuanya dalam membentuk koping baru untuk mengatasi depresi pada lansia, sehingga secara garis besar dapat ditarik kesimpulan bahwa terapi murotal mempunyai dua poin penting, memiliki irama yang indah dan juga secara psikologis dapat memotivasi dan memberikan dorongan semangat dalam menghadapi problem yang sedang dihadapi.

Sejalan dengan penelitian yang dilakukan Ardiansyah (2014) tentang perbedaan efektivitas terapi musik klasik dengan murottal terhadap tingkat kecemasan mahasiswa semester akhir dengan hasil $\mathrm{P}=0,018(\mathrm{p}<0,05)$, menyimpulkan bahwa pemberian terapi musik klasik dan muratal sangat efektif dalam menurunkan tingkat kecemasan pada mahasiswa tingkat akhir. Dalam hal ini musik murottal lebih efektif dibandingkan musik klasik.

Manajemen pencegahan dan terapi yang dapat diberikan pada kondisi stress, cemas dan depresi memerlukan pendekatan secara farmakologis yaitu mencakup perilaku, kognitif, meditasi hipnotis dan musik (Hardjana, 2006dalam Garry, 2014). Metode musik merupakan salah satu cara untuk mengatasi depresi. Secara keseluruhan musik dapat berpengaruh secara fisik maupun psikologis. Secara psikologis musik dapat membuat seseorang menjadi rileks, mengurangi stres, menurunkan depresi, menimbulkan rasa aman dan sejahtera, melepaskan gembira dan sedih, dan membantu melepaskan rasa sakit (Djohan, 2006dalam Garry, 2014).

\section{SIMPULAN}

Berdasarkan hasil penelitian tentang keefektifan dari terapi musik klasik dengan terapi muratal pada gejala kecemasan; fase 2 terhadap lansia di Panti Werdha Binjai, yang dapat kami simpulkan sebagai berikut:

1. Bahwa karakteristik responden yaitu berdasarkan jenis kelamin, dimana responden laki-laki sebanyak 16 orang $(47,1 \%)$ dan responden perempuan sebanyak 18 orang $(52,9 \%)$. Berdasarkan karakteristik umur yaitu paling banyak responden berada pada usia antara 61-70 tahun yaitu sebanyak 16 orang (47,1\%), diikuti responden usia antara 71-80 tahun sebanyak 11 orang $(32,4 \%)$, selanjutnya responden usia antara 50-60 tahun sebanyak 5 orang $(14,7 \%)$ dan paling sedikit responden usia lebih dari 80 tahun yaitu ada 2 orang $(5,9 \%)$. Berdasarkan suku yaitu paling banyak responden suku Batak yaitu sebanyak 13 orang $(38,2 \%)$, diikuti responden suku Jawa sebanyak 11 orang $(32,4 \%)$, selanjutnya responden suku Banjar dan suku Melayu masing-masing sebanyak 2 orang $(5,9 \%)$ dan paling sedikit responden suku Banten, Betawi, NTT, Aceh, Kaimantan dan Minang yaitu masing-masing ada 1 orang $(2,9 \%)$. Berdasarkan pendidikan terakhir yaitu paling banyak responden dengan tingkat pendidikan terakhir SD/SR yaitu sebanyak 18 orang $(52,9 \%)$, diikuti responden dengan tingkat pendidikan terakhir SMP yaitu sebanyak 11 orang $(32,4 \%)$ dan paling sedikit responden dengan tingkat pendidikan terakhir SMA/sederajat sebanyak 5 orang $(14,7 \%)$.

2. Bahwa responden dengan gejala kecemasan fase 2 sebelum terapi music klasik cukup baik ada 9 orang $(26,5 \%)$, kurang baik sebanyak 25 orang $(73,5 \%)$ dan tidak ada lansia yang memiliki gejala kecemasan baik. Setelah responden melakukan terapi music klasik ada peningkatan sedikit yaitu responden dengan gejala kecemasan fase 2 cukup baik bertambah 5 orang menjadi 14 orang (41,2\%), kurang baik berkurang 5 orang menjadi 20 orang $(58,8 \%)$ dan tidak ada responden dengan gejala kecemasan baik.

3. Bahwa perbedaan gejala kecemasan fase 2 pada lansia sebelum terapi musik klasik dan terapi muratal adalah rata-rata sebesar 0,02941dengan standar deviasi sebesar 0,17150. Hal ini menunjukkan bahwa terapi music klasik lebih efektif kurang dari 0,03 kali dibandingkan terapi muratal yaitu lebih efektif sebesar 0,089 kali terhadap gejala kecemasan fase 2 pada lansia. Hasil analisis statistic dengan menggunakan $u j i$ paired t-test menunjukkan p-value sebesar 0,325 , artinya tidak ada perbedaan efektivitas terapi music klasik dengan terapi muratal sebelum perlakuan terhadap gejala kecemasan fase 2 pada lansia di Panti Werdha Binjai.

4. Bahwa perbedaan gejala kecemasan fase 2 pada lansia sesudah terapi musik klasik dengan terapi muratal adalah rata-rata sebesar 1,38235 dengan standar deviasi sebesar 0,60376. Terapi muratal lebih efektif 1,59 kali dibandingkan terapi music klasik yaitu sebesar 1,17169 kali terhadap gejala kecemasan fase 2 pada lansia. Hasil analisis statistic dengan menggunakan uji paired t-test menunjukkan bahwa p-value sebesar 0,000, artinya ada perbedaan yang sangat signifikan antara efektivitas terapi music klasik dengan terapi muratal sesudah perlakuan terhadap gejala kecemasan fase 2 pada lansia di Panti Werdha Binjai.

\section{SARAN}

1. Kepada lansia yang sudah mendapat terapi muratal dan memiliki pengetahuan yang baik diharapkan untuk terus mempertahankan dan meningkatkan terapi disaat lagi santai di tempat tinggal dengan tujuan untuk mempertahankan dan menurunkan kecemasan perlahan-lahan. Hal ini harus dilakukan karena terapi muratal lebih efektif daripada terapi musik klasik.

2. Kepada petugas kesehatan yang bertugas di Panti Werdha Binjai memiliki kemampuan dan waktu untuk memberikan terapi muratal kepada lansia yang selalu mengalami kecemasan fase 2 dengan tujuan untuk 
memberikan motivasi kepada lansia yang sering mengalami gejala tersebut.

3. Untuk lansia yang sering melakukan terapi muratal dengan baik agar membagikan pengetahuan dan pengalamannya kepada lansia yang lain, agar lansia yang lain ikut termotivasi dengan langkah yang dilakukan lansia yang berhasil menurunkan kecemasannya.

4. Kepada keluarga lansia yang memiliki waktu untuk datang menjenguk agar tetap memberikan motivasi kepada keluarganya untuk terus selalu melakukan terapi muratal agar selalu ingat kepada Allah SWT, dan tetap menjalankan ibadahnya dengan khusyuk.

\section{DAFTAR PUSTAKA}

1. Abdurrochman, A.,Wulandari, R.D. and Fatimah, N. 2007.The Comparison of Classical Music, Relaxation Music and The Qur'anic

2. Agustian, Ary G, 2001. Kecerdasan Emosi dan Spiritual. Arga, Jakarta.

3. Ayub Sani Ibrahim (2003), Panik Neurosis dan Gangguan Cemas, Jakarta : PT. Dua As - As

4. Bodner M, Muftuler LT, Nalcioglu O, Shaw GL. FMRI study relevant to Mozart

5. Djohan, 2006, Ensiklopedia Musik dan terapinya, Gramedia Jakarta

6. Djohan. 2006. Terapi Musik teori dan aplikasi. Yogyakarta. Galangpress

7. Garry Ardiansyah. 2014. Pengaruh Terapi Musik Klasik Dan Murotal Terhadap Penurunan Tingkat Stres Mahasiswa S1 Semester Akhir Universitas Muhammadiyah Surakarta. Naskah Publikasi. Program Studi Fisioterapi. Fakultas Ilmu Kesehatan. Universitas Muhammadiyah Surakarta.

8. Hardjana, D, 2009. Musik dan Dampak Bagi Kehidupan. WYKN. http://www.inChrist.net. Tanggal Akses 18 September 2017

9. Ike Rossyam Wardani, S. 2015. Pengaruh Terapi Musik Klasik Dan Murottal Terhadap Penurunan Tingkat Depresi Pada Lansia. Naskah Publikasi. Program Studi S1 Fisioterapi Fakultas Ilmu kesehatan Universitas Muhammadiyah Surakarta.

10. Lehtonen K. Some ideas about music therapy for the elderly. Voices:A World Forum For Music Therapy [ serial online] 2002;2(1). http://www. voices.no/mainissues/Voices2(1)Lehtonen.html

11. Mindlin, 2009. Brain Music. http: //www.editinternational.com Tanggal Akses: 10 Agustus 2015

12. Prasetyo, Bambang dan Lina Miftahul Jannah.2008.Metode Penelitian Kuantitatif: teori dan Aplikasi.Jakarta: PT. Raja Grafindo Perkasa

13. Rahmawati, 2005, Ensiklopedia Musik dan manfaatnya, PT. Rineka, Jakarta

14. Remolda, P. 2009. Pengaruh Al-quran pada Manusia dalam Perspektif Fisiologi dan Psikologi. http://www.theedc.com

15. Rochman, W. \& Aswin, S. (2001). Tua dan Proses Menua. Berkala Ilmu kedokteran Vol. 33, No 4.
16. Stuart \& Sundeen, 1998. Buku Saku Keperawatan Jiwa (Pocket Guide to Psyciatric Nursing). Edisi 3, Alih bahasa; Achir Yani S Hamid, Jakarta:EGC.

17. Sunarto, Achmad. (Eds), 1999. Terapi Penyakit Dengan Al-Qur'an dan Sunnah. Pustaka Amani, Jakarta.

18. Soekidjo Notoadmodjo. 2002. Metodologi Penelitian Keperawatan. Jakarta Rineka Cipta

19. Undang Undang Republik Indonesia Nomor 13 Tahun 1998 Tentang Kesejahteraan Lansia (1998). Jakarta

20. Weinberger NM. "The Mozart Effect": A small part of the big picture. MUSICA Research Notes [serial online] 2000;7(1) http://www.musica.uci.edu.

21. Widodo, T, 2009. Metode Penelitian Kuantatif. UNS press, Surakarta. 